\title{
Correction to: Uniportal Versus Multiportal Video-Assisted Thoracoscopic Lobectomy for Lung Cancer: An Updated Meta-analysis
}

\author{
Dimitrios E. Magouliotis $^{1,2,3}$ (1) $\cdot$ Maria P. Fergadi $^{4} \cdot$ Kyriakos Spiliopoulos $^{5} \cdot$ Kalliopi Athanassiadi $^{3}$
}

Published online: 4 March 2021

(c) The Author(s) 2021

\section{Correction to: Lung (2021) 199:43-53 \\ https://doi.org/10.1007/s00408-020-00411-9}

The article "Uniportal versus multiportal video-assisted thoracoscopic lobectomy for lung cancer: an updated metaanalysis" written by Dimitrios E. Magouliotis, Maria P. Fergadi, Kyriakos Spiliopoulos, and Kalliopi Athanassiadi, was originally published Online First without Open Access. After publication in volume 199, issue 1, page 43-53, the author decided to opt for Open Choice and to make the article an Open Access publication. Therefore, the copyright of the article has been changed to () The Author(s) 2021 and the article is forthwith distributed under the terms of the Creative Commons Attribution 4.0 International License, which permits use, sharing, adaptation, distribution and reproduction in any medium or format, as long as you give appropriate credit to the original author(s) and the source, provide a link to the Creative Commons licence, and indicate if changes were made. The images or other third party material in this article are included in the article's Creative Commons licence, unless indicated otherwise in a credit line to the material. If material is not included in the article's Creative Commons licence and your intended use is not permitted by statutory regulation or exceeds the permitted use, you will need to obtain permission directly from the copyrightholder. To view a copy of this licence, visit http:// creativecommons.org/licenses/by/4.0.

The original article has been corrected.

Open Access This article is licensed under a Creative Commons Attribution 4.0 International License, which permits use, sharing, adaptation, distribution and reproduction in any medium or format, as long as you give appropriate credit to the original author(s) and the source, provide a link to the Creative Commons licence, and indicate if changes were made. The images or other third party material in this article are included in the article's Creative Commons licence, unless indicated otherwise in a credit line to the material. If material is not included in the article's Creative Commons licence and your intended use is not permitted by statutory regulation or exceeds the permitted use, you will need to obtain permission directly from the copyright holder. To view a copy of this licence, visit http://creativecommons.org/licenses/by/4.0/.

Publisher's Note Springer Nature remains neutral with regard to jurisdictional claims in published maps and institutional affiliations.

The original article can be found online at https://doi.org/10.1007/ s00408-020-00411-9.

Dimitrios E. Magouliotis

dimitrios.magouliotis.18@ucl.ac.uk

1 Division of Surgery and Interventional Science, Faculty of Medical Sciences, UCL, London, UK

2 Department of Surgery, University of Thessaly, Biopolis, 41110 Larissa, Greece
3 Unit of Thoracic Surgery, Evangelismos Hospital, Athens, Greece

4 Faculty of Medicine, University of Thessaly, Biopolis, Larissa, Greece

5 Department of Thoracic and Cardiovascular Surgery, Larissa University Hospital, Larissa, Greece 